\title{
III. 旰移植の病理
}

\section{山邊 博彦 羽賀 博典 南口早智子}

本庄 原 水田 直美 白瀬 智之

\section{要 旨}

移植後における移植肝機能障害の原因としては, 臟器保存・再灌流障害, 吻合手術と関連した合併 症, 拒絶反応, 肝炎, 胆管炎, 移植後リンパ増殖性疾患, 原病の再発などをあげることができる. 本 稿では,これらの病変の臨床病理学的特徵を述べた. 臨床的には, 肝機能検查データのみからではこ れら相互間の鑑別診断が容易ではなく，肝生検所見が診断確定の“Gold standard”とされる.

[日内会誌 $90: 78 \sim 83,2001$ ]

Key words : 肝移植, 病理診断, 拒絶反応

\section{1. 移植肝障害の原因と肝生検の意義}

移植肝機能障害の原因としては, 蔵器保存 · 再灌流障害, 吻合手術と関連した合併症, 拒絶 反応, 肝炎, 胆管炎, 移植後りンパ増殖性疾患, 原病の再発などをあげることができるる ${ }^{1.2)}$. 臨床 検查データのみからではこれら相互間の鑑別診 断が容易ではなく，肝生検所見が診断確定に必 要であり, “Gold standard”とされる1).

\section{2. 臓器保存・再灌流障害}

臓器保存 - 再灌流障害は移植時の冷阻血, 温 阻血および再灌流による移植肝障害であるが, 脳死肝移植においてはドナーの死亡直前に起 こった障害も同時に含まれていることが多い。 移植後数日から通常 $2 \sim 3$ 週間の間に見られる 小葉中心性の肝細胞の風船状変性と胆汁栕滞を

やまべひろひこ,はがひろのり,みなみぐち さちこほんじょうげんみずた なおみ，しらせ ともゅき:京都大学病理部・葴器移植医療部
主とする病変で，虚血による細胆管の障害が原 因と考えられている，肝細胞の核分裂像増加や 単細胞壊死, 場合によっては小葉中心性虚血性 壊死もみられる．血清ビリルビンの高值が続く が，予後は良好でやがて正常に復する。

\section{3. 伆合手術に関連した合併症}

移植の際には, 肝動脈, 肝静脈, 門脈, 胆管 の吻合が行われるが，その手術操作に関連して 吻合部の狭窄, 閒塞, あるいは吻合不全を来し, その結果肝障害を惹起する場合がある.

肝動脈血栓症では，小葉中心性の虚血性の凝 固壊死や変性, 門脈域における細胆管増生など がみられ，高度な場合は広範な梗塞をきたす。 肝静脈狭窄では小葉中心性の㯊血, 出血, 肝細 胞の萎縮または壊死が見られ, やがて線維化を きたし，門脈域を中心に中心静脈周囲の線維化 が連なったいわゆる reversed lobulationの構造 を示す. 門脈の狭窄では, 小葉中心性の肝細胞 の萎縮, 脱落が主な所見であり, その結果類洞 の拡張をきたす. 
胆管の吻合不全や狭窄が起これば, 肝内の胆

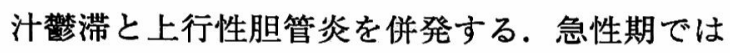

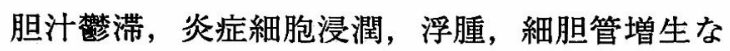
どがみられ，慢性化すれば，胆管周囲の層状の 線維化が見られる。胆管の拡張, 細胆管増生, さらに時には胆管消失も伴い，小葉内には胆汁 楚滞と肝細胞の網状壤死が見られることもあ る.

\section{4. 拒絶反応}

ドナーとレシピエントの間のHLA（human leukocyte antigen) やABO血液型抗原などの いわゆる組織適合性抗原の相違による免疫反応 である．進行すれば移植臓器の機能廃絶を招来 し再移植が必要となるため, 臨床的には早期診 断と適切な治療が極めて重要である. 肝移植の 拒絶反応は, 細胞性免疫反応機序が想定される 急性および慢性拒絶反応と液性反応機序が考え られる液性拒絶反応に分類される.

1）急性拒絶反応 (acute rejection)

主として小葉間胆管上皮と門脈および中心静 脈の血管内皮を傷害する可逆性の拒絶反応であ る. 移植後 1 週間から $1 \sim 2$ カ月に多く見られ る最も一般的な拒絶反応である.

基本的な病理組織学的三所見（triad）は（1） 門脈域の炎症，（2）胆管の炎症と傷害，（3）静 脈の血管内皮炎 (endotheliitis) である(図 1 ). 門脈域の炎症はリンパ球, 好酸球, 好中球を含 むいわゆる混合性炎症細胞浸潤であり, 高度に なると門脈域を拡大し更に周辺肝実質へも浸潤 して肝細胞壊死を伴う. 胆管病変は主として小 葉間の小胆管に見られ, 胆管上皮間や胆管周囲 への炎症細胞浸潤と胆管上皮の傷害, すなわち 上皮配列不整, 核胞体比の増加, 胞体の好酸性 の増加, 腺管構造の破壊として見られる. 静脈 性血管内皮炎（図 2 ） は門脈と中心静脈に見ら れ, 内皮直下へのリンパ球の浸潤による内皮挙 上と破壊を示す. なお, 小葉中心性の肝細胞の

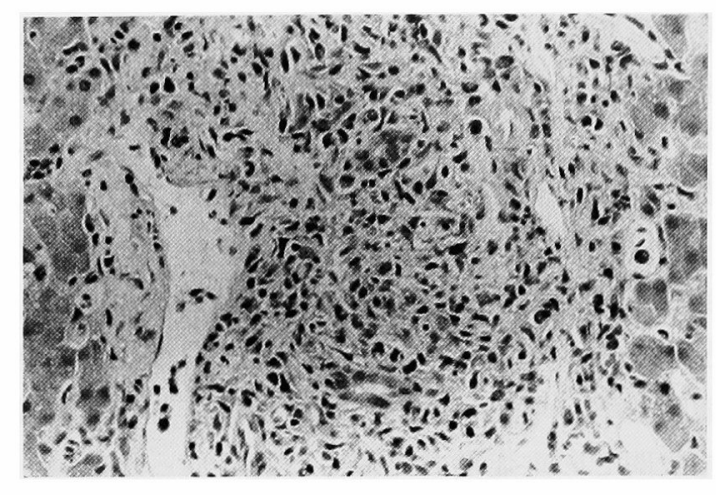

図 1. 急性拒絶反応: 門脈域に混合炎症細胞浸潤が みられる。(H \& E × 20)

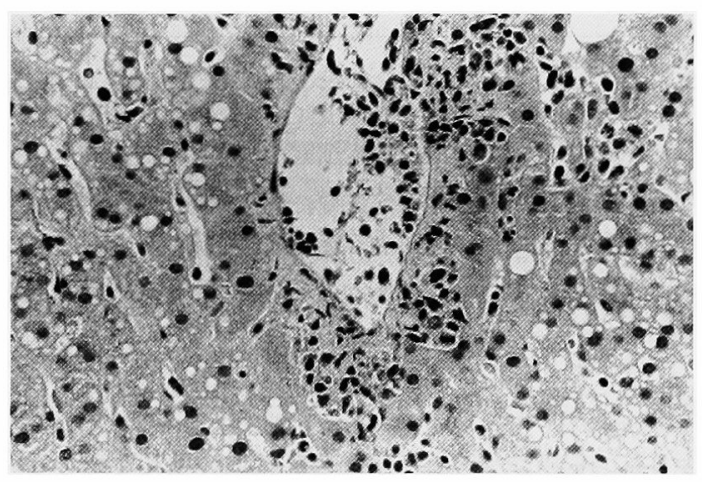

図 2．急性拒絶反応：門脈に血管内皮炎がみられる. (H \& E × 20)

脱落を伴う中心静脈周囲の炎症細胞浸潤の所見 は一時免疫抑制剂タクロリムスの副作用とも考 えられたが, 最近では急性拒絶反応の一所見と 考えられている.

従来客観的基準のなかった急性拒絶反応の病 理組織学的重症度分類 (grading) についての 国際的基準が1995年の第 3 回移植病理Banff会 議においてBanff schema $^{3)}$ として発表され, 現 在世界中の多くの施設において使用されている (表 1,2 ). この基準では, 急性拒絶反応の診 断基準として, 上記の三所見（triad）のうち の少なくとも二所見が存在することが必要と規 定し, そのうえで, 急性拒絶反応の重症度分類 を,まず組織像の全体的評価（global assessment）として表 1 に示す基準に従って四重症 
度に分類し，さらに半定量的評価（semi-quantitative assessment) として門脈域の炎症, 胆 管の炎症/傷害, 静脈内皮炎の 3 項目について, 表 2 に示す基準に従ってそれぞれのスコア（0 ～3）を求め，それを加算して得られたスコア 総計（ $0 \sim 9 ）$ をRA (Rejection Acitvity Index) として記載する。この方法により, 重症度に客 観的基準が与えられ，数量化が可能となり，多 施設間での重症度の比較も可能となった。

表 1. 肝移植の急性拒絶反応の重症度分類に関する Banff Schema：(1) 全体評価（重症度）

\begin{tabular}{cl}
\hline \multicolumn{1}{c}{ 全体評価 } & \multicolumn{1}{c}{ 基準 } \\
\hline Indeterminate: & 急性拒絶反応の基準を満たさない門 \\
(不確実) & 脈域の炎症細胞浸潤 \\
Mild: & 一部の門脈域に見られ, 軽度で門脈域 \\
(軽度) & に限局する炎症細胞浸潤 \\
Moderate: & 全部または大部分の門脈域に広がる \\
(中等度) & 炎症細胞浸潤 \\
Severe: & 上記Moderateの所見に加えて, 門脈 \\
(高度) & 域周边への炎症細胞浸潤の逸出と, 肝 \\
& 実質へ広がり肝細胞の壊死をともな \\
& う中心静脈周辺の㷋症細胞浸潤 \\
\hline
\end{tabular}

臨床的には急性拒絶反応は軽度の場合は無症 状であるが, 高度の場合は, 発熱, 肝腫大, 肝 部痛，チアノーゼなどを来す。血液検査では， 白血球增多症, 好酸球增多症がみられ, 肝機能 検查ではGOT/GPT（AST/ALT）の上昇に加 え， $\gamma$ GTPやALPなどの胆道系酵素，およびビ リルビン值の上昇が見られる．適当な免疫抑制 治療により多くは軽快するが，治療の不適当な 例, 治療抵抗性の例, 重症度の高い例, あるい は繰返す拒絶反応を示す例などのなかに慢性拒 絶反応へ移行する例があるので注意を要する.

2）慢性拒絶反応（chronic rejection）

急性拒絶反応に引き続いて発症し，結果的に 胆管および血管に非可逆的な障害をもたらしう る拒絶反応を慢性拒絶反応という．同義語とし て胆管減少性拒絶反応 (ductopenic rejection), 胆管消失症候群 (vanishing bile duct syndrome)，あるいは動脈閉塞性拒絶反応 (obliterative arteriopathic rejection) などの名称も使われて きたが，胆管抢よび血管病変はそれぞれこの病 変の一側面にすぎず，その全体像を表していな いので,これらは適当な名称ではない。

表 2、肝移植の急性拒絶反応の重症度分類に関する Bannf Schema：(2) 半定量的䛨価（RAI）

\begin{tabular}{cll}
\hline 項目 & 基準 & Score \\
\hline
\end{tabular}

門脈域の炎症：一部の門脈域において門脈域の应大を伴わないリンパ球を主とする漫潤 1

(P)

少数の芽球を含むりンパ球，好中球，好酸球の混合細胞浸潤による大部分または全部の門脈 2 域の拡大

多くの芽球を含むりンパ球，好中球，好酸球の混合細胞浸潤による大部分または全部の門脈 3 域の拡大で，門脈域周辺肝奏質へ炎症細胞逸出を伴うもの

胆管の炎症／障害：一部の胆管周团への炎症細胞浸潤と胆管上皮の核胞体比の增加など軽度の反応性変化 1 (B)

大部分または全部の胆管への炎症細胞浸潤としばしば見られる胆管の核の多形性,極性の乱 2 れ，胞体の空胞変性などの変性性変化

上記変化と，大部分または全部の胆管の変性性変化または胆管腔破壊 3

静脈内皮炎：一部の門脈・中心静脈の内皮下リンパ球浸潤

(V)

大部分または全部の門脈・中心静脈内皮下リンパ球浸潤

上記変化と, 中等度ないし高度の肝実質へ広がり肝細胞壊死を伴う静脈周辺の細胞浸潤 3

Rejection Activity Index (RAI) $=(\mathrm{P})+(\mathrm{B})+(\mathrm{V})$ 


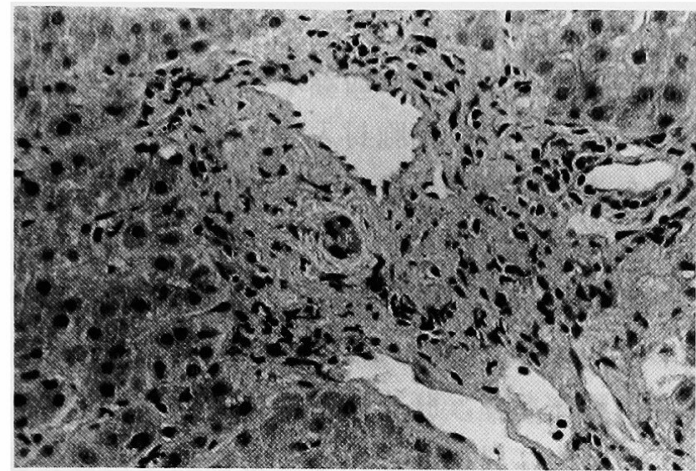

図 3. 慢性拒絶反応：胆管の変性がみられ，炎症細 胞浸潤も減少してきている. 早期の慢性拒絶反応の所 見である. $(\mathrm{H} \& \mathrm{E} \times 20)$

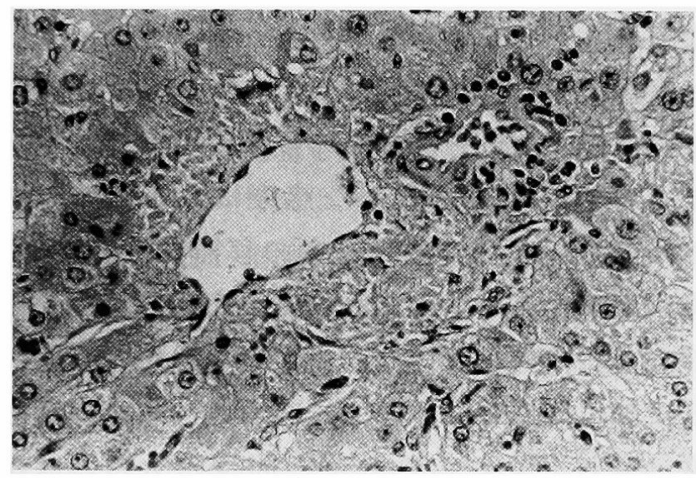

図 4. 慢性拒絶反応: 門脈域の胆管が消失. ( $\mathrm{H} \& \mathrm{E}$ $\times 20$ )

病理組織学的には, 慢性拒絶反応は基本的に （1）胆管病変と，(2) 閉塞性動脈病変よりなる. 胆管病変は小葉間胆管の変性と消失であり（眓 3), 閉塞性動脈病変は, 肝門部に近い比較的 太い肝動脈枝の内膜下への泡沫組織球の浸潤を 伴う血管内腔閉塞性病変である（図 4 ）. 生検 で診断できる主要な所見は前者であり, 後者は 存在すればそれだけで診断が確定するが, 生検 において見られることは殆どない.

慢性拒絶反応の従来の診断基準は最低20個の 門脈域における50\%以上の胆管消失か閉塞性動 脈病変の確認であったが, この基準で診断され た場合, 臨床的にはすでに末期状態で治療が無 効であった. そこで, 治療可能な早期に慢性拒

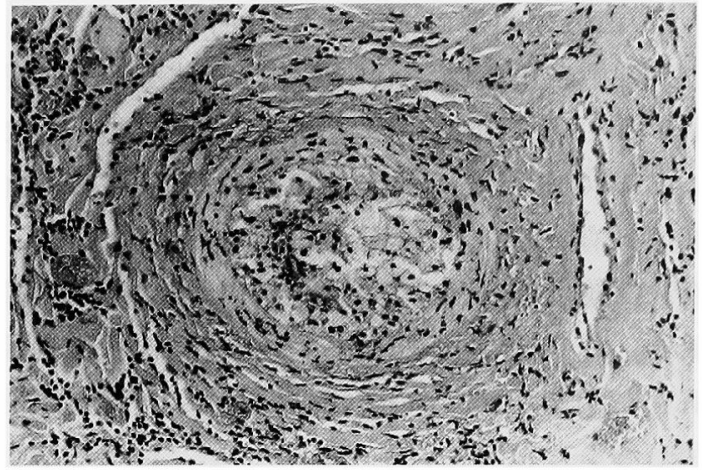

図 5. 慢性拒絶反応: 肝動脈枝に内皮下への泡沫組 織球の出現による閉塞が見られる。摘出肝にみられた 動脈閉塞病変である. $(\mathrm{H} \& \mathrm{E} \times 10)$

絶反応を予知する診断基準がながらく求められ ていた. 1999年の第 5 回移植病理Banff会議4)で はこれに答えて慢性拒絶反応の病理学的病期の 検討と, 早期病変の病理組織学的診断基準に関 する討議が行われた. それによると, 早期病変 は胆管の萎縮と変性であり, 胆管上皮の胞体の 好酸性変化, 核の配列不整, 核の大型化と濃染 化, 上皮の部分的脱落が主な所見である.この 診断には胆管の50\%以上の消失は必要とせず， 診断に必要な門脈域の数の規定もない.この時 期では, 強力な拒絶反応の治療により治療可能 である.さらに病変が進行し末期に近づくと多 くの門脈域における胆管の消失が見られ, 病変 は非可逆的となる。

慢性拒絶反応は通常移植後 2 - 3 カ月以上を 経てから発症するが，それ以前に発症すること もある. 重症で治療抵抗性あるいは頻回に再発 する急性拒絶反応に続いて発生することが多い が, 時に何の前兆もなく起こることもある. 肝 機能検査では進行性のビリルビン值の増加と胆 道系酵素の上昇がみられる。血管造影等で肝動 脈の血流の異常がみられることがある。慢性拒 絶反応の頻度は, かって欧米の脳死肝移植にお いては平均約10\%であったが，最近は免疫抑制 治療の進歩と早期病変に対する適切な対処のた めに減少傾向にあり，4～5\%といわれる. 
3）液性拒絶反応（humoral rejection）

液性拒絶反応は，液性抗体と補体を介して発 生する拒絶反応である．原因となる抗体として は, ABO血液型不適合移植における抗ABO血 液型抗体と抗ドナーHLA抗体が問題となる. 液性拒絶反応発症の危険因子として, 過去の移 植歴, 妊娠歴, 輸血歴, ABO血液型不適合移 植などが知られており，異種移植における拒絶 反応もこの範疇に属する.

掯移植では移植前から存在した抗体による移 植直後（超急性）に発症する激しい拒絶反応が 超急性拒絶反応（hyperacute rejection）と呼 ばれて知られており，もしこれが肝に発症すれ ば移植後数時間から 1 日以内に洷出性変化と動 脈炎を伴う肝臓の凝固壤死により肝機能は廃絶 するが, 肝移植では極めて稀である.他方, ABO 血液型不適合移植等においては移植後 2 3週で 液性拒絶反応によると考えられる肝動脈血栓症 を発症し，肝梗塞にて機能廃絶を見ることがあ り，また胆管病变を合併して慢性胆管炎に移行 する場合がある.ABO血液型不適合移植では 肝動脈内皮が抗血液型抗体の標的で胆管病変は 肝動脈病変に二次的に生じた虚血性胆管炎であ ると考えられる.

\section{5. 肝炎}

移植後にみられる肝炎は, 日和見感染のウイ ルス肝炎, 肝炎ウイルス肝炎, 敗血症に伴う感 染性肝炎, 自己免疫性肝炎, 薬物肝炎など多彩 である。

日和見感染ウイルス肝炎では, サイトメガロ ウイルス, Epstein-Barr (EB) ウイルス, 単 純ヘルペスウイルス,アデノウイルス等による ものが見られるが, サイトメガロウイルスと $\mathrm{EB}$ ウイルスが重要である. サイトメガロウイルス 感染症は移植後 2 8 週間頃, しばしば急性拒 絶反応の治療後に発症し, 発熱と下痢, 白血球 - 血小板減少, 異型リンパ球出現, 肝機能検査
異常が見られ，末梢血中にサイトメガロウイル 不抗体を有する多核白血球が検出される，肝病 変では小葉内の巨細胞封入体形成と好中球のみ よりなる微小脿場形成が診断的所見である。封 入体には免疫組織化学的にサイトメガロウイル ス抗原が陽性に染色される．EBウイルス感染 症では, 発熱, 咽頭炎症状, 脾腫, 異型リンパ 球の出現があり，肝病変があれば，門脈域およ び肝小葉内に異型リンパ球を含む炎症細胞の浸 潤を見る。これらのリンパ球はEBER (EB virus encoded small RNA) のin situ hybridizationで 陽性である，適切な治療を行わなければ後述す る移植後りンパ増殖性疾患（PTLD）の原因と なる。

B型肝炎，C型肝炎などの肝炎ウイルスによ る肝炎は, ドナー肝からの侵入, レシピエント からの再発および新たな感染によるものがあ る. $\mathrm{HBcAb}$ 陽性ドナーからの移植肝でもB型肝 炎が再発することが知られている。初期は急性 肝炎の組織像を示すが, 半年ほどの経過で慢性 肝炎の組織像を呈するようになる。組織像は通 常の急性および慢性肝炎と同様のもののほか に, 移植肝に独特なFibrosing cholestatic hepatitisとよばれる重症慢性肝炎がB型のみならず C型肝炎においてもみられ，門脈域の急性細胆

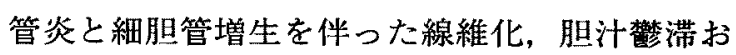
よび著しい肝細胞腫大を特徴とする。

敗血症の場合には小葉中心性の毛細胆管性胆 汁椱帯と類洞への好中球の浸潤など肝炎様の組 織像とともに門脈域の胆管内およびその周囲人 の好中球の浸潤と胆汁栓形成がみられ胆管增生 を伴うのが特徴である。

自己免疫性肝资や原発性胆汁性肝硬変は後述 するように原病の再発として見られることがあ る.また，移植肝にde-novoの自己免疫性肝炎 が発生しうることが知られている.

薬物性肝炎は肝細胞障害型, 胆汁檏滞型ある いはこの両者の混合型など急性肝炎のあらゆる 形をとり得るため鑑別診断が問題となる，原因 
の楽剤の使用を中止して病変が軽快することを 確認できれば診断が確定する。

\section{6. 胆管炎}

上述の胆管吻合に関係する胆管炎，敗血症の 胆管炎，ABO血夜型不適合移植にみられる胆 管炎，さらに原病の再発として原発性硬化性胆 管炎などをみることがある。

\section{7. 移植後リンパ増殖性疾患 (Post-trans-} plant lymphoproliferative disease, PTLD)

PTLDは移植後に発生する翼型りンパ球の増 殖の著しい病変で, リンパ節や消化管その他の 節外性の部位に腫瘤を形成する，強い免疫抑制 状態で発生しやすく, 殆どの例でEBウイルス が証明される. 肝移植ではその約 2 は $3 \%$ に発 症する，病変の組織学的分類はいろいろと提唱 されているが, 病変を早期病変, 多形性PTLD, および一般の悪性リンパ腫の形態をとるPTLD の 3 種類に分類するのが妥当と考えられる，治 療はまず免疫抑制の中止で病変の縮小, 消失を みることが多い。必要であれば抗りンパ腫治療 を行う。

\section{8. 原病の再発}

腫瘍では肝細胞癌および肝芽腫, ウイルス感 染症ではB型およびC型肝炎, 自己免疫疾患で は原発性胆汁性肝硬変, 自己免疫性肝炎, 原発 性硬化性胆管炎などの原病の再発が報告されて
七.

\section{9. 生体肝移植の肝障害の特徵}

血縁者間の生体肝移植311例のデータ5にによ ると, 臟器保存・再灌流障害の頻度は低く, そ の程度も軽いこと，急性拒絶反応は期待した程 頻度が低くないが，HLA-A，BおよびDRのミ スマッチ遗伝子座の多いほど急性拒絶反応の頻 度が高い傾向にあること, 慢性拒絶反応の頻度 が低いと思われることなど，生体肝移植の有利 な点が明らかとなった. 欧米の脳死肝移植と血 縁者生体肝移植を比較したデータでも，生体肝 移植では臓器保存・再灌流障害が軽度であり， 急性拒絶反応には頻度の差はないもののステロ イド治療抵抗性拒絶反応と慢性拒絶反応の頻度 は低かったと報告している。

\section{文献}

1）山造博彦, 他：III，肝陚移植。日本移植学会・日本病 理学会編. ヒト移植臟器拒絶反応の病理組織診断基準 ・第 1 版. 東京. 金原出版. 1998:55-78.

2) 山邊博彦：肝移植の病理. 診断病理 $17: 112-119,2000$.

3) Demetris AJ, et al: (An International Panel). Banff schema for grading liver allograft rejection: An international consensus document. Hepatology 25 : 658-663, 1997.

4) Demetris AJ, et al (An International Panel) : Update of the international schema for liver allograft rejection. Working recommendations for the histopathological staging and reporting of chronic rejection. Hepatology $2000: 31,792-798$.

5) Minamiguchi $\mathrm{S}$, et al : Living related liver transplantation : Histopathological analysis of graft dysfunction in 304 patients. Hum Pathol 30: 1479-1487. 1999. 